DOI 10.7251/SCMED1802092B UDC 796.035.015:616-008.9:577.125 COBISS.RS-ID 7836696

\section{Bone Metabolism Markers and their Correlation with Body Mass Index in Aerobic Physical Activity}

\section{ABSTRACT}

Introduction: Bone formation marker osteocalcin $(\mathrm{OC})$ and bone resorption marker C-terminal telopeptide of type 1 collagen (CTX) can be used to detect or to monitor the early responses of the skeleton to physical activity. Literature suggests that it is likely that higher body mass index (BMI) has positive effect on bones and can postpone onset of osteoporosis.

Aim of the Study: The aim of this study is to:

1. Determine the effect of aerobic physical acitivity on OC and CTX in young women

2. Investigate correlation of OC, CTX and BMl in young women engaged into structured aerobic excercise

Material and methods: Study included 64 healthy young women, aged 19 to 25 years, devided into two groups: intervention group $(n=32)$ and control group $(n=32)$. The study duration was six weeks with follow-up period of four weeks. The intervention group underwent structured aerobic physical activity program for six weeks, but the control group did not receive such program. Level of OC, CTX and BMI were measured at baseline, after 6-week aerobic program, and after 4-week follow up (only intervention group).

Results: There was significant increase of OC level after 6-week aerobic program, while level of CTX did not changed. OC level was at its maximum immediately after finishing the program in the participants with normal BMI $(p<0.001)$. There was no statistically significant interaction of BMI and CTX level.

Conclusion: Aerobic physical activity increases level of osteocalcin, suggesting that it has positive influence on bone formation in young women, primarily in women with normal BMI.

Key words: osteocalcin, C-terminal telopeptide of type 1 collagen, bone metabolism, aerobic physical activity

(Scr Med 2018:49:92-98)
Zorislava Bajicí, Nela Rašeta ${ }^{2}$, Nenad Ponorac ${ }^{1}$

${ }^{1}$ Department of Physiology, Faculty of Medicine, University of Banja Luka, Banja Luka, Republic of Srpska, Bosnia and Herzegovina ${ }^{2}$ Department of Pathophysiology, Faculty of Medicine, University of Banja Luka, Banja Luka, Republic of Srpska, Bosnia and Herzegovina

Corresponding author:

Zorislava Bajić,

e-mail:

zorislava.bajic@med.unibl.org
Manuscript received: October $10^{\text {th }}, 2018$ Manuscript accepted: November $12^{\text {th }}, 2018$ 


\section{Introduction}

A Bone remodeling involves two continuous processes that occur as a result of body weight and physical activity: bone resorption and bone formation. These two processes are essential in maintaining skeletal homeostasis. Physical deformation of the bone cells, achieved by physical activity, is essential for maintenance of bone strength. Bone adapts its form to meet the physical demands placed on it by changing its size and density. ${ }^{1}$ The body weight and potential energy from the earth's gravity will pass through the bones and joints, forcing the bones and joints in the legs to bear the whole body weight and causing the leg muscles to contract more as they try to maintain balance. This stimulates activity of bone cells (osteoblasts) and the compression on the bones increases the process of mineralization of the bones. ${ }^{2-4}$ Muscle contraction is a major force that have great influence on bone mineralization. The effects of exercise on the bones is assessed in terms of physical strain such as the weight of the ground against the body standing on it, i.e. ground-reaction force, or muscle contraction forces on a particular area of bone.5,6 Weight bearing activity is essential for normal development and maintenance of bone health. ${ }^{7}$ Even though swimming is not a weight bearing activity, Derman and colleagues found that swimmers have a higher bone mineral density compared to the control group. It is believed that the main reason for this is that they usually exercise with small weights and a lot of repetition, which may be sufficient stimuli to increase bone metabolism. ${ }^{8}$

There is a close relationship between metabolic bone markers and bone mineral density (BMD); for example, osteocalcin is significantly correlated with BMD in postmenopausal women with osteoporosis. ${ }^{9}$ Among the metabolic bone markers, C-terminal telopeptide of type 1 collagen (CTX) is shown to be more sensitive and more specific to bone resorption than other conventional measurements, such as urinary hydroxyproline and urinary calcium excretion. ${ }^{10}$ Besides, bone turnover markers can be indirectly used to detect or to monitor the early responses of the skeleton to weight-bearing exercise. ${ }^{11,12}$ Biochemical markers are very sensitive to physical activity: their progressive increase occurs 30 minutes from the beginning of exercise (up to $45-50 \%$ ). ${ }^{13}$

Body mass index (BMI) is a parameter that determines the health risk. Specifically, correlation between BMI and the onset of osteoporosis has been the subject of many studies. For example, Coin and colleagues came to the conclusion that the values of $\mathrm{BMI}<22$ in young adults may carry a higher risk of the onset of osteoporosis in older age, especially in women.14 Hence, literature suggests that it is likely that higher BMI has a positive effect on bones (and therefore reduced risk toward osteoporosis). ${ }^{14,15}$ To our knowledge the effect of structured aerobic exercise on bone markers and specifically their relation to BMI (and therefore osteoporosis) in young adults is still not fully understood. According to the position stand on bone health and physical activity of the American College of Sports Medicine (ACSM), moderate-to-high intensity, weight-bearing endurance activities are recommended to help preserve or to increase BMD in adults.1 The level of BMD in later life is a function of the maximum bone mass attained in early adulthood and of subsequent age-related bone loss, which starts in the fourth decade of life and accelerates in early postmenopausal years in women. ${ }^{16-18}$ De Jong and colleagues sugested that aerobic physical activity is associated with an increase in BMD in a population with an increased risk for osteoporosis. ${ }^{19}$

\section{Aim of the Study}

Given the potential benefit of physical activity to bone markers and BMI our aim is to:

1. Determine the effect of aerobic physical activity on bone metabolism markers: osteocalcin (OC), the bone formation marker, C-terminal telopeptide of type 1 collagen (CTX), the bone resorption marker, in young women

2. Investigate correlation of OC, CTX and BMI in young women engaged into structured aerobic excercise

\section{Material and methods}

Current study included 64 healthy young women, aged 19 to 25 years, divided into two groups: intervention group $(n=32)$ and control group $(n=32)$. All participant were not involved in any kind of physical activity before entering the study. The research protocol followed the principles of the Declaration of Helsinki regarding biomedical research involving human subjects. All participants provided written consent subsequent to being informed about the research process.

The study duration was six weeks with follow-up period of four weeks. Intervention group underwent 6-week aerobic physical activity. The aerobic exercise program was consisted of $45 \mathrm{~min}$ supervised aerobic exercise sessions two times a week. The supervision and exercise guidance was done by highly skilled professional in physical education and sport. The program consisted of:

- $\quad$ step aerobics for ten minutes

- $\quad$ easy running for five minute

- $\quad$ exercises for the shoulders, arms and legs (in the 
form of squats) - a total duration of fifteen minutes

- exercises for the abdominal and gluteal musculature - ten minutes

- a relaxation exercise - five minutes.

While the subjects in the intervention group underwent aerobic physical activity program for six weeks, the subjects in the control group did not receive such program. Blood samples for osteocalcin (OC) and C-terminal telopeptide of type 1 collagen (CTX) were taken at 8 a.m. and analyzed by ECLIA immunoassay method on Roche Elecsys 2010. Body weight and height are measured in the morning as well. BMI was calculated by applying the Quetelét equation: the division of weight (kg) by height $(\mathrm{m})$ squared. Normal BMI for adults is 18.5 to $24.9 \mathrm{~kg} / \mathrm{m} 2$, persons with BMI below $18.5 \mathrm{~kg} / \mathrm{m} 2$ are underweight, above $25.0 \mathrm{~kg} / \mathrm{m} 2$ are overweight.20 Both groups were assessed at baseline, after 6 weeks and after 4-week follow up (only intervention group). Purpose of the follow up period for the intervention group was to investigate long term effects of aerobic physical activity on bone metabolism markers (OC and CTX).

Osteocalcin level in the intervention group was statistically significantly higher after 6-week program compare to the baseline ( $\mathrm{p}<0.001)$, and after 4 -week follow up compare to the baseline ( $\mathrm{p}=0.005)$. In the control group, there was no significant difference in osteocalcin level $(p=0.952)$.
The collected data were analyzed by statistical analysis by SPSS 17.0.1 (SPSS Inc., Chicago, IL, USA), and statistical significance was set as $\mathrm{p}<0.05$.

\section{Results}

At baseline there was no observable difference in age, BMI and bone metabolism markers between intervention (IG) and control group (CG) (Table 1).

Table 1. Age and BMI at baseline both intervention (IG) and control group (CG) $(n=64)$

\begin{tabular}{cccccc} 
& \multicolumn{2}{c}{ IG $(\mathrm{n}=32)$} & \multicolumn{2}{c}{$\mathrm{CG}(\mathrm{n}=32)$} & $\mathrm{p}$ \\
& Median & IQR & Median & IQR & \\
\hline Age & 20 & $(20-21)$ & 20 & $(20-21)$ & 0.338 \\
\hline $\mathrm{BMl}$ & 21 & $(20-23)$ & 21 & $(20-23)$ & 0.868 \\
$\left(\mathrm{~kg} / \mathrm{m}^{2}\right)$ & & & & & \\
\hline
\end{tabular}

\footnotetext{
* Values are presented as median and interquartile range (IQR)

$n$ - number of subjects
}

The statistical analysis showed that the level of CTX in the intervention group was not statistically significantly different $(\mathrm{p}=0.243)$ in all tree measurements, nor in the control $(\mathrm{p}=0.264)$ in two measurement (Table 2$)$.

Table 2. OC and CTX in intervention (three measurements) and control group (two measurements)

\begin{tabular}{|c|c|c|c|c|c|c|c|c|}
\hline & \multicolumn{4}{|c|}{$\mathrm{OC}(\mathrm{ng} / \mathrm{ml})$} & \multicolumn{4}{|c|}{ CTX (ng/ml) } \\
\hline & $\begin{array}{c}\text { IG } \\
M(S D)\end{array}$ & $\mathrm{p}$ & $\begin{array}{c}C G \\
M(S D)\end{array}$ & $p$ & $\begin{array}{c}\text { IG } \\
M(S D)\end{array}$ & $p$ & $\begin{array}{c}\text { CG } \\
M(S D)\end{array}$ & $p$ \\
\hline Baseline & 30.2 & \multirow{3}{*}{$<0.001^{\star}$} & 32.1 & \multirow{3}{*}{0.952} & 0.52 & \multirow{3}{*}{0.243} & 0.52 & \multirow{3}{*}{0.264} \\
\hline & $(7.57)$ & & $(9.52)$ & & $(0.16)$ & & $(0.156)$ & \\
\hline $\begin{array}{l}\text { After } 6 \text {-week } \\
\text { program }\end{array}$ & $\begin{array}{c}34.3 \\
(10.01)\end{array}$ & & $\begin{array}{c}32.0 \\
(7.73)\end{array}$ & & $\begin{array}{c}0.56 \\
(0.20)\end{array}$ & & $\begin{array}{c}0.55 \\
(0.191)\end{array}$ & \\
\hline \multirow{2}{*}{$\begin{array}{l}\text { After 4-week } \\
\text { follow-up }\end{array}$} & 32.5 & \multirow[t]{2}{*}{$0.005^{\star \star}$} & & & 0.54 & & & \\
\hline & (7.50) & & & & $(0.19)$ & & & \\
\hline
\end{tabular}

Values are presented as mean (M) and standard deviation (SD)

${ }^{*}$ Statistically significant difference of OC level at the baseline and after 6-week program

${ }^{*}$ Statistically significant difference of OC level at the baseline and after 4-week follow up 
For underweight subjects $\left(\mathrm{BMI}<18.5 \mathrm{~kg} / \mathrm{m}^{2}\right)$ of intervention group there was no statistically significant difference in the level of osteocalcin in all three measurements $(\mathrm{p}=0.903)$, as well as in overweight (BMI $>25 \mathrm{~kg} / \mathrm{m} 2)$ subjects $(\mathrm{p}=0.067)$. There is, however, significant increase of OC after the 6-week aerobic program in subjects with normal BMI $(\mathrm{p}<0.001)$. Conducted mixed analysis of variance (within groups and between groups) showed that there was no statistically significant interaction of time of measurement and body mass index on the value of CTX $(p=0.360)$ (Table 3$)$.

Table 3. OC and CTX level compare to BMI in intervention group

\begin{tabular}{|c|c|c|c|c|c|c|c|c|}
\hline & \multicolumn{4}{|c|}{ OC (ng/ml) } & \multicolumn{4}{|c|}{ CTX (ng/ml) } \\
\hline & Baseline & $\begin{array}{c}\text { After 6-week } \\
\text { program }\end{array}$ & $\begin{array}{l}\text { After 4-week } \\
\text { follow-up }\end{array}$ & $p$ & Baseline & $\begin{array}{l}\text { After 6-week } \\
\text { program }\end{array}$ & $\begin{array}{l}\text { After 4-week } \\
\text { follow-up }\end{array}$ & $p$ \\
\hline & $M(S D)$ & $M(S D)$ & $\mathrm{M}(\mathrm{SD})$ & & $\mathrm{M}(\mathrm{SD})$ & $M(S D)$ & $\mathrm{M}(\mathrm{SD})$ & \\
\hline $\begin{array}{l}\text { Under } \\
\text { weight }\end{array}$ & $\begin{array}{l}25.1 \\
(5.15)\end{array}$ & $\begin{array}{l}25.2 \\
(7.96)\end{array}$ & $\begin{array}{l}25.8 \\
(6.56)\end{array}$ & 0.903 & $\begin{array}{c}0.4 \\
(0.19)\end{array}$ & $\begin{array}{c}0.4 \\
(0.25)\end{array}$ & $\begin{array}{c}0.4 \\
(0.23)\end{array}$ & \\
\hline $\begin{array}{l}\text { Normal } \\
\text { weight }\end{array}$ & $\begin{array}{c}31.5 \\
(7.96)\end{array}$ & $\begin{array}{l}37.6 \\
(9.0)\end{array}$ & $\begin{array}{l}34.5 \\
(6.95)\end{array}$ & $<0.001^{\star}$ & $\begin{array}{c}0.6 \\
(0.15)\end{array}$ & $\begin{array}{c}0.6 \\
(0.18)\end{array}$ & $\begin{array}{c}0.6 \\
(0.18)\end{array}$ & 0.360 \\
\hline $\begin{array}{c}\text { Over } \\
\text { weight }\end{array}$ & $\begin{array}{l}29.8 \\
(5.35)\end{array}$ & $\begin{array}{c}26.6 \\
(5.26)\end{array}$ & $\begin{array}{l}30.8 \\
(6.92)\end{array}$ & 0.067 & $\begin{array}{c}0.4 \\
(0.08)\end{array}$ & $\begin{array}{c}0.5 \\
(0.19)\end{array}$ & $\begin{array}{c}0.5 \\
(0.18)\end{array}$ & \\
\hline
\end{tabular}

Values are presented as mean (M) and standard deviation (SD)

* Statistically significant difference of OC level in subjects with normal BMI

\section{Discussion}

It is well known that a young bone adapts better to mechanical stress and physical activity than a mature bone. This means that exercising in early childhood is an important factor in prevention of osteoporosis later in life.7 Peak bone mass is achieved by age $30 .{ }^{21}$ Due to these reasons, for our study we chose women between 19 and 25 years old. We wanted to investigate how changes in bone metabolism occur at this age, as well as the dynamics of these changes.

Theoretically, the duration of the human boneremodeling cycle takes about 4-6 months, and the durations of resorption and formation are not evenly divided. The osteoclastic resorption activity (at a specific site) accounted for 3-6 weeks, followed by osteoblastmediated bone formation, which accounted for $5^{-9}$ weeks. Hence, a 6-week exercise program is more feasible than a long-term exercise program (e.g., 2030 weeks) to investigate bone turnover markers rather than bone mineral accumulation. ${ }^{22}$ Based on the concept of bone metabolism, bone health can be estimated via biochemical markers of bone turnover other than densitometric indices. ${ }^{23}$
The results of the current study showed that the 6-week aerobic program increased level of OC, therefore it had the great impact on bone formation, while the level of CTX did not changed, suggesting that program had no influence on bone resorption. The value of $\mathrm{OC}$ after one month of relative resting was higher than at the baseline. This suggests a protective effect of physical activity holds also after the completion of exercising.

The results of previous studies on bone turnover and exercise have been inconsistent. ${ }^{24,25}$ In a study of mice, results showed significant negative effects on serum CTX (exercise caused a quick reduction in bone turnover). Similar results were demonstrated by Klentrou and colleagues. ${ }^{25}$ After 12 weeks of exercise, bone resorption marker, N-telopeptide of type I collagen (NTX), decreased by $14.5 \%$ in the intervention group, while there were no significant changes in the osteocalcin levels. ${ }^{25}$ Similarly, in the Wen's study, the changes in the serum CTX levels were significantly different between groups after a 10-week step aerobic exercise; the intervention group showed a trend in down regulating bone resorption activity, which was reflected by a reduction of CTX. ${ }^{22}$ This is positively benefited to bone formation. The serum CTX level, was in a declining trend after the 10- 
week step aerobic exercise, suggesting that short term exercise program may likely be effective in preventing bone loss and in enhancing bone formation. ${ }^{22}$ Similar results were also obtained by Roghani and colleagues, who found increase in bone-specific alkaline phosphates and decrease in NTX after a 6-week, moderate-intensity (50-60 \% HER) aerobic (walking on a treadmill) exercise in postmenopausal women with osteoporosis. ${ }^{26}$ However, the findings of Phoosuwan, Kritpet and Yuktanandana ${ }^{27}$ were inconsistent with those of Roghani et al.. The study showed reductions in both NTX and bone-specific alkaline phosphatase after a 12-week, weight-bearing yoga training program. These mixed down regulations of bone turnover might be due to disparities in exercise mode and intensity. ${ }^{22,26,27}$

Adami and colleagues conducted a study that included eumenorrheic women aged 39 to 45 years, without cardiovascular diseases, fractures and other chronic diseases. The intervention group entered 4-weeks exercise program with continuously increasing intensity of exercise. In the intervention group was found a significant increase of $25 \%$ in bone formation markers OC and N-terminal propeptide of procollagen I (PINP) compared with the control group..$^{28}$ Those results are consistent with results of current study. In Adami's study $^{28}$ there was no statistically significant change in serum CTX, nor was in ours.

Mullins and Sinning, however, showed that 12 weeks of resistance exercise for 18 to 30 years old women, lead to a reduction in BAP as a marker of bone formation, whereas osteocalcin was not significantly changed (contrary to our results). Deoxypyridinoline (DPD), bone resorption marker, rose to a higher level than normal. ${ }^{29}$ Results similar to ours are demonstrated with study of Jürimäe and colleagues in which $\mathrm{OC}$ in rowers, who were preparing for the competition, was increased, whereas the other markers were not significantly changed. ${ }^{30}$

In current study the biggest impact of the physical activity on bone metabolism, specifically values of OC, occurred in young women with normal body mass index. In other words, current study has shown that the best effects of physical activity on bone can be expected in women with normal BMI. A similar results had Cui and colleagues ${ }^{15}$, suggesting that a normal BMI can be protective factor against osteoporosis. While other studies showed negative correlation between osteocalcin and BMI, ${ }^{31-33}$ even that obese women had lower prevalence of osteopenia and osteoporosis compared to normal weight subjects. ${ }^{31}$

\section{Conclusion}

This research showed that aerobic physical activity increases level of osteocalcin, suggesting that it has positive influence on bone formation in young women, primarily in women with normal BMI. This results could be used as a framework for making program for osteoporosis prevention.

Current study had some limits that need to be mentioned. This was a short-term intervention study that focused on the changes of bone metabolic markers. In the future study should consider longer follow up period, to evaluate time frame of OC protective effect. The study should include measurement of BMD and analyze others bone metabolism markers, such as sclerostin, which is a protein that acts as an inhibitor of bone formation. ${ }^{34}$

\section{References}

1. Kohrt WM, Bloomfield SA, Little KD, Nelson ME, Yingling VR. ACSM Position Stand: physical activity and bone health. Med Sci Sports Exerc 2004; 36: 1985-96.

2. Hinton PS, Rector RS, Thomas TR. Weight-bearing, aerobic exercise increases markers of bone formation during shortterm weight loss in overweight and obese men and women. Metabolism 2006; 55(12): 1616-18.

3. Anek A, Kanungsukasem V, Bunyaratavej N. Effects of the circuit box jumping on bone resorption, health-related to physical fitness and balance in the premenopausal women. Journal of the Med Assoc Thai 2011; 94 (Suppl 5): S17-23.

4. Multanen J, Nieminen MT, Häkkinen A, Kujala UM, Jamsa $\mathrm{T}$, Kautiainen $\mathrm{H}$, et al. Effects of high-impact training on bone and articular cartilage: 12-month randomized controlled quantitative MRI study. Bone Miner Res 2014; 29(1): 192-201.

5. Heinonen A, Sievänen H, Kannus P, Oja P, Pasanen M, Vuori I. High-impact exercise and bones of growing girls: a 9-month controlled trial. Osteoporos Int 2000; 11(12): 1010-17.

6. Marques EA, Mota J, Viana JL, Tuna D, Figueiredo P, Guinaites JT, et al. Response of bone mineral density, inflammatory cytokines, and biochemical bone markers to a 32-week combined loading exercise programme in older men and women. Archives of Gerontology and Geriatrics 2013; 57(2): 226-33.

7. The international federation of sports medicine. FIMS Position Statement. Scientific Commentary: Osteoporosis and Exercise. Available at: http://www.fims.org/ files/7314/2056/2483/PS11-Scientific-CommentaryOsteoporosis-and-Exercise.pdf (accessed September 19, 2018).

8. Derman O, Cinemre A, Kanbur N, Doğan M, Kiliç M, Karaduman E. Effect of swimming on bone metabolism in adolescents. Turk Pediatr 2008: 50: 149-54.

9. Delmas PD. Biochemical markers of bone turnover. I: theoretical considerations and clinical use in osteoporosis. Am Med 1993; 95(5), Suppl 1: 11S-16S. 
10. Delmas PD, Schlemmer A, Gineyts E, Riis B, Christiansen C. Urinary excretion of pyridinoline crosslinks correlates with bone turnover measured on iliac crest biopsy in patients with vertebral osteoporosis. Bone Miner Res 1991; 6(6): 639-44.

11. Lester ME, Urso ML, Evans RK, Pierce JR, Spiering BA, Marech CM, et al. Influence of exercise mode and osteogenic index on bone biomarker responses during short-term physical training. Bone 2009; 45(4): 768-76.

12. Ratamess NA, Hoffman JR, Faigenbaum AD, Mangine GT, Falvo MJ, Kang J. The combined effects of protein intake and resistance training on serum osteocalcin concentrations in strength and power athletes. Strength Cond Res 2007; 21(4): 1197-03.

13. Guillemant J, Accarie C, Peres G. Guillemant S. Acute effects of an oral calcium load on markers of bone metabolism during endurance cycling exercise in male athletes. Calcif Tissue Int 2004; 74: 407-14.

14. Coin A, Perissinotto E, Enzi G, Zamboni M, Inelmen EM, Frigo AC, et al. Predictors of low bone mineral density in elderly: the role of dietary intake, nutritional status and sarcopenia. Eur Clin Nutr 2008; 62: 802-09.

15. Cui R, Zhou L, Li Z, Li Q, Qi Z, Zhang J. Assessment risk of osteoporosis in Chinese people: relationship amog body mass index, serum lipid profiles, blood glucose, and bone mineral density. Clinical Interv Aging 2016; 11: 887-95.

16. Beitz R, Dören M. Physical activity and postmenopausal health. Br Menopause Soc 2004; 10(2): 70-74.

17. Chan K, Qin L, Lau M, Woo J, Au S, Choy W, et al. A randomized, prospective study of the effect of Tai Chi Chun exercise on bone mineral density in postmenopausal women. Archives of Physical Medicine and Rehabilitation 2004; 85(5): 717-22.

18. Stear SJ, Prentice A, Jones SC, Cole TJ. Effect of calcium and exercise intervention on the bone mineral status of 16-18-y-old adolescent girls. Am Clin Nutr 2003; 77(4): 985-92.

19. De Jong Z, Munneke M, Lems WF, et al. Slowing of bone loss in patients with rheumatoid arthritis by long-term high-intensity exercise. Arthritis Rheum 2004; 50(4): 1066-76.

20. Salinari S, Bertuzzi A, Mingrone G, Capristo E, Scarfone A, Greco AV, Heymsfield SB. Bioimpedance analysis: a useful technique for assessing appendicular lean soft tissue mass and distribution. J Appl Physiol 2003: 94: 1552-56.

21. Nickols-Richardson SM, Miller LE, Wooten DF, Ramp WK, Herbert WG. Concentric and eccentric isokinetic resistance training similarly increases muscular strength, fat-free soft tissue mass and specific bone mineral measurements in young women. Osteoporos Int 2007: 18: 789-96.

22. Wen HJ, Huang TH, Li TL, Chong PN, Ang BS. Effects of short-term step aerobics exercise on bone metabolism and functional fitness in postmenopausal women with low bone mass. Osteoporosis International 2017; 28(2): 539-47.

23. Seeman E, Delmas PD. Bone quality-the material and structural basis of bone strength and fragility. N Engl Med 2006; 354:2250-61.

24. Friedman MA, Bailey AM, Rondon MJ, McNerny EM, Sahar ND, Kohn DH. Calcium- and phosphorussupplemented diet increases bone mass after short-term exercise and increases bone mass and structural strength after long-term exercise in adult mice. PLoS One 2016; 11(3): e0151995.

25. Klentrou P, Slack J, Roy B, Ladouceur M. Effects of exercise training with weighted vests on bone turnover and isokinetic strength in postmenopausal women. J Aging Phys Activ 2007; 15: 287-99.

26. Roghani T, Torkaman G, Movasseghe S, Hedayati M, Goosheh B, Bayat N. Effects of short-term aerobic exercise with and without external loading on bone metabolism and balance in postmenopausal women with osteoporosis. Rheumatol Int 2013; 33(2): 291-8.

27. Phoosuwan M, Kritpet T, Yuktanandana P. The effects of weight bearing yoga training on the bone resorption markers of the postmenopausal women. J Med Assoc Thailand 2009; 92 (Suppl 5): S102-S108.

28. Adami S, Gatti D, Viapiana O, Fiore CE, Nuti R, Luisetto G, et al. Physical activity and bone turnover markers: A crosssectional and longitudinal study. Calcif Tissue Int 2008; 83: 388-92.

29. Mullins NM, Sinning WE. Effects of resistance training and protein supplementation on bone turnover in young adult women. Nutr Metab 2005; 2: 19.

30. Jürimäe J, Purge P, Jürimäe T, Von Duvillard SP. Bone metabolism in elite rowers: adaptation to volume-extended training. Eur J Appl Physol 2006; 97: 127-32.

31. Mazocco L, Chagas P. Association between body mass index and osteoporosis in women from northwestern Rio Grande do Sul. Rev Bra Reumatol (English Edition) 2017; 57(4): 299-305

32. Handrijantini N, Alie R, Setiawati R, Astuti ER, Wardhana MP. The correlation of bone mineral density (BMD), body mass index (BMI) and osteocalcin in postmenopausal women. Biol Med 2016; 8(6): 1000319.

33. Maddaloni E, D’Onofrio L, Lauria A, et al. Osteocalcin levels are inversely associated with Hba1c and BMI in adult subjects with long-standing type 1 diabetes. Endocrinol Invest 2014; 37(7): 661-6.

34. Zagrodna A, Jóźków P, Medraś M, Majda M, SlowińskaLisowska M. Sclerostin as a novel marker of bone turnover in athletes. Biol Sport 2016; 33(1): 83-7. 


\section{Markeri metabolizma kosti i njihova korelacija sa indeksom tjelesne mase $u$ aerobnoj fizičkoj aktivnosti}

\section{SAŽETAK}

Uvod: Marker formiranja kosti osteocalcin (OC) i marker resorpcije kosti C-terminalni telopeptid kolagena tipa 1 (CTX) se mogu koristiti za određivanje i praćenje ranog odgovora kosti na fizičku aktivnost. Podaci iz literature pokazuju da veći indeks tjelesne mase (body mass index - BMI) ima pozitivni efekat na kost i može da odloži nastanak osteoporoze.

Cilj rada: Cilj ovog sitraživanja je:

1. Utvrditi efekat aerobne fizičke aktivnosti na OC i CTX kod mladih žena

2. Ispitati povezanost OC, CTX i BMI kod mladih žena uključenih u program aerbne fizičke aktivnosti

Materijali i metode: Istraživanje je obuhvatalo 64 zdrave mlade žene starosti od 19 do 25 godina, koje su podijeljene u dvije grupe: eksperimentalnu ( $n=32)$ i kontrolnu $(n=32)$ grupu. Istraživanje je trajalo šest nedjelja uz period praćenja u trajanju od 4 nedjelje. Eksperimentalna grupa je bila uključena u program strukturisane aerobne fizičke aktivnosti u trajanju od šest nedjelja, a kontrolna grupa nije imala fizičku aktivnost u tom periodu. Mjerene su vrijednosti OC, CTX i BMI na početku, nakon šest nedjelja pomenutog programa i nakon četiri nedjelje od završetka programa (samo eksperimentalna grupa).

Rezultati: Postoji statistički značajno povećanje vrijednosti OC nakon šestonedjeljne aerobne fizičke aktivnosti, dok se vrijednost CTX nije značajno promijenila. Maksimalna vrijednost OC je bila neposredno po završetku programa kod učesnica sa normalnim BMI $(p<0,001)$. Nije bilo statistički značajne interakcije BMI i vrijednosti CTX.

Zaključak: Aerobna fizička aktivnost povećava nivo osteokalcina, što ukazuje na pozitivan uticaj na formiranje kosti kod mladih žena, naročito kod žena sa normalnim BMI.

Ključne riječi: osteocalcin, C-terminalni telopeptid kolagena tipa 1, metabolizam kosti, aerobna fizička aktivnost 